\title{
Pruskie sądy administracyjne gwarantem praw podmiotowych? Organizacja sądów i praktyka orzecznicza Najwyższego Sądu Administracyjnego (OVG) a prawa polskiej mniejszości narodowej (1875-1914)
}

I. Pojęcie „sąd administracyjny” zasadnie kojarzy się z wyrównywaniem szans obywateli, jako słabszej strony sporu z organem administracji rządowej czy samorządowej. Istnienie tych sądów nierozerwalnie związane jest z konstrukcją państwa prawa. Nawet tam, gdzie przyjmuje się, że odrębnych sądów administracyjnych nie powołano, vide Wielka Brytania, wiele spraw sporno-administracyjnych trafiało nie do sądów powszechnych, a szczególnych wyspecjalizowanych trybunałów ${ }^{1}$. Inne kraje zachodu akceptowały powoli konieczność wprowadzenia sądowej kontroli nadużyć administracji wobec obywatela i ta przybierała różne formy, których klasyfikacja ma raczej niesporny charakter; nie ma potrzeby jej przywoływania w tym miejscu. Jednakże w niektórych państwach doszło do powołania szczególnych sądów - trybunałów, stojących na straży praw obywatelskich, zwłaszcza tych zagwarantowanych konstytucyjnie, czego przykładem mogą być kraje Niemiec południowych ${ }^{2}$ czy monarchia habsburska. W tym ostatnim kraju kontrola

${ }^{1}$ Por. L. Bar, Sadowa kontrola administracji w Anglii, Warszawa 1962, s. 197-228.

${ }^{2} \mathrm{Z}$ nowszych prac na temat bardzo ciekawego procesu rozwoju gwarancji konstytucyjnych wobec praw obywatelskich w krajach niemieckiego południa por. przykładowo O. Müller, Die Verfassungsbeschwerde nach Bayerischen Verfassung von 1818 (1818-1848). Ein Beitrag zur Geschichte der Verfassungs- und Verfassungsgerichtsbarkeit in Deutschland, Frankfurt am Main 2000. Z kolei rozwój sądowych organów kontroli administracji omówił G. Sydow, Die Verwaltungsgerichtsbarkeit des ausgehenden 19. Jahrhunderts. Eine Quellenstudie zu Baden, Württem- 
administracji przyjęła postać nie tylko jednoinstancyjnych trybunałów: Państwa i Administracyjnego, ale spoczywała także częściowo w gestii sądów powszechnych $^{3}$. Z drugiej jednak strony amerykański federalny Sąd Najwyższy dowiódł przez długi czas swego istnienia, jak wszechstronny potrafi być w roli gwaranta praw sąd powszechny w składzie zaledwie 9 sędziów, z których wielu nie było wcześniej zawodowymi sędziami.

Prusy nie powołały odrębnego sądu dla ochrony praw konstytucyjnych, czy też inaczej praw podstawowych. Ta kategoria pozostawała zresztą w prawie i doktrynie wyjątkowo mglista, o czym będzie jeszcze mowa. Czy zatem gwarantem praw obywatelskich mogły być sądy administracyjne? Jakie były ku temu sposobności, a jakie przeszkody? W niniejszym opracowaniu spróbowano wskazać główne aspekty tego zagadnienia.

II. Z perspektywy krajów Europy Zachodniej, Prusy spóźniły się może z wprowadzeniem sądów administracyjnych, ale wśród krajów niemieckich mieszczą się w średniej. Byli prekursorzy (Badenia - 1863), ale też i ariergarda (Saksonia - 1900). Równolegle zapadły rozstrzygnięcia w Austrii, chwilę później w Bawarii. Dyskusje między zwolennikami Justizstaatsmodell i Administrativjustiz toczyły się już zresztą od pierwszych dziesięcioleci XIX w. ${ }^{4}$, jednak jak wskazują inne przykłady z niemieckiej historii prawa, burzliwa temperatura dyskursu mogła nawet opóźniać przyjęcie rozwiązań ustawowych. Późniejszy prezydent Najwyższego Sądu Administracyjnego (Oberverwaltungsgericht, dalej: OVG) w Berlinie, Bill Drews, podkreślał, że obawiano się utraty autorytetu władzy publicznej, która: ,gleich dem Bürger,

berg und Bayern mit einem Anhang archivalischer und parlamentarischen Quellen, Heidelberg 2000; analogicznie dla Brunszwiku T. Henne, Verwaltungsrechtsschutz im Justizstaat. Das Beispiel des Herzogtums Braunschweig 1832-1896, Frankfurt am Main 1995.

${ }^{3}$ Wiele pisał na ten temat w ostatnich latach Andrzej Dziadzio. Poza znakomitą monografią: Monarchia konstytucyjna w Austrii 1867-1914 (Władza, obywatel, prawo), Kraków 2001, należy przywołać też jego drobniejsze przyczynki. Por. idem: Koncepcja państwa prawa w XIX w. -idea i rzeczywistość, „Czasopismo Prawno-Historyczne” 57 (2005), z. 1, s. 177-201; Ochrona konstytucyjności prawa w Europie XIX wieku, „Studia z Dziejów Państwa i Prawa Polskiego” 11 (2008), s. 171, 177-183; Znaczenie najwyższych trybunatów sądowych w tworzeniu podstaw państwa prawa w austriackiej monarchii konstytucyjnej po 1867 roku, [w:] Świat, Europa, Mała Ojczyzna. Studia ofiarowane Profesorowi Stanisławowi Grodziskiemu w 80-lecie urodzin, red. M. Małecki, Bielsko-Biała 2009, s. 419-425.

${ }^{4}$ Por. chociażby klasyczne prace: O. Bähr, Der Rechtsstat. Eine publizistische Skizze, 2. unveränd. Aufl., Kassel-Göttingen 1864; R. v. Gneist, Der Rechtsstaat und die Verwaltungsgeschichte, 1879. Zagadnienie to podsumował m.in. L. Pahlow, Administrativjustiz versus Justizstaat. Justiz und Verwaltung im Allgemeinen Staatsrecht des 18. Und 19. Jahrhunderts, „Zeitschrift für neuere Rechtsgeschichte", 22. Jg (2000), Nr 1, s. 11-30. Z kolei Georg-Christoph von Unruh zwięźle podsumował spory doktrynalne na temat kształtu i postępowania przed sądami administracyjnymi między von Gneistem i Lorenzem von Steinem. Por. idem, Verwaltungsgerichtsbarkeit im Verfassungsstaat, Herford 1984, s. 39-52. 
der sich in seinem Rechte verletzt fühlt, als gewöhnliche Partei in mündlicher Verhandlung Rede und Antwort stehen mu $\beta$ "5.

Za regulacjami prawnymi dotyczącymi sądów administracyjnych stał w państwie Hohenzollernów słynny prawnik i polityk, Rudolf von Gneist (1816-1895) ${ }^{6}$. Początki właściwych sądów administracyjnych wiązały się $\mathrm{z}$ wydaniem ordynacji powiatowej $\mathrm{w} 1872 \mathrm{r} .{ }^{7} \mathrm{~W}$ budowie podwalin prawnych rozróżnić należy dwa etapy: pierwszy - to wprowadzenie sądów administracyjnych w pięciu wschodnich pruskich prowincjach w latach $1872-1876^{8}$, drugi - rozszerzenie funkcjonowania sądownictwa administracyjnego na wszystkie prowincje pruskie, co zakończyło się w $1890 \mathrm{r} .{ }^{9}$

Należy przypomnieć, że sądami pierwszej instancji pozostawały samorządowe wydziały powiatowe (Bezirksausschüsse), złożone z landrata jako przewodniczącego i 6 członków-ławników, wybieranych na okres 6 lat przez sejmik powiatowy ${ }^{10}$. W powiatach miejskich (Stadtkreise) działał odpowiednio wydział miejski (Stadtausschuß), złożony z burmistrza jako przewodniczącego oraz 4 członków. W drugiej instancji, na szczeblu obwodu rejencyjnego (Regierungsbezirk), działały obwodowe sądy administracyjne (Bezirkverwaltungsgerichte). W ich skład wchodziło 5 członków, w tym 3 ławników wybieranych przez wydział prowincjonalny (Provinzialausschuß), zaś 2 mia-

5 ,[...] musiałaby wystąpić w postępowaniu ustnym jako zwykła strona, przemawiająca i odpowiadająca, obok obywatela, który czuje, że jego prawa zostały naruszone" (tłum. własne). Cyt. za: G.-Ch. von Unruh, Die Verwaltungsrechtsschutz in Preussen und seine Bedeutung für die rechtsstaatliche Entwicklung in Deutschland, „Forschungen zur Brandenburgischen und Preussischen Geschichte", Neue Folge 4 (1994), s. 110.

${ }^{6}$ Por. szerzej D. Esser, Gneist, Rudolf [w:] Juristen. Ein biographisches Lexikon, hrsg. von M. Stolleis, München 1995, s. 238-239.

${ }^{7}$ Kreisordung für die östlichen Provinzen Preussen, Brandenburg, Pommern, Posen, Schlesien und Sachsen z 13 grudnia 1872 r. (Gesetz-Sammlung für Königlichen Staaten Preussen, [dalej: GS] s. 661), ze zmianami z 19 marca 1881 r. (GS, s. 179).

${ }^{8}$ Podstawa prawna jest obszerna. Obejmuje ordynację powiatową, ordynację prowincjonalną - Provinzialordnung für die Provinzen Ost- und Westpreussen, Brandenburg, Pommern, Schlesien und Sachsen z 29 czerwca 1875 r. (GS, s. 355) ze zmianami z 22 marca 1881 r. (GS, s. 233), ustawę o ustroju sądów administracyjnych i spornym postępowaniu administracyjnym z 3 lipca 1875 r Gesetz betreffend die Verfassung der Verwaltungsgerichte und das Verwaltungsstreitverfahren (GS, s. 375) ze zmianami z 2 sierpnia 1880 r. (GS, s. 328) oraz tzw. ustawę kompetencyjną z 26 lipca 1876 r. - Gesetz betreffend die Zuständigkeit der Verwaltungsbehörden im Geltungsbereiche der Provinzialordnung vom 29.6.1875, (GS, s. 297). Początkom sądownictwa administracyjnego swą rozprawę doktorską poświęcił N. Nowatius. Por. idem, Die Einführung der Verwaltungsgerichtsbarkeit in Preußen durch die Kreisordnung von 1872 unter besonderer Berücksichtigung der Verdienste von Eduard Lasker (Jur. Diss.), [b.m.w.], 2000.

${ }^{9} \mathrm{Na}$ podstawie ustawy o ogólnej administracji kraju z 30 lipca 1883 r. - Das Gesetz über allgemeine Landesverwaltung (GS, s. 155) oraz nowej ustawy o właściwości władz administracyjnych i sądowoadministracyjnych z 1 sierpnia 1883 r. - Gesetz über die Zuständigkeit der Verwaltungsund Verwaltungsgerichtsbehörden (GS, s. 237).

${ }^{10} \mathrm{Na}$ mocy $\S 130,131$ i 136 ordynacji powiatowej. 
nowanych dożywotnio przez króla ${ }^{11}$. Wykluczony był wybór do sądu nadprezydenta prowincji, prezesa rejencji, landrata czy naczelników władz policyjnych. W 1883 r. doszło do przeobrażenia sądu obwodowego w wydział obwodowy (Bezirkaussschuß), utrzymano jego sądowniczą funkcję i dodano czwartego ławnika. Jeden z zastępców prezesa rejencji, członków wydziału, nosił wprost tytuł dyrektora sądu administracyjnego. W Poznańskiem, gdzie jak zazwyczaj nowe regulacje weszły w życie z opóźnieniem, w 1890 r., ustanowiono od razu wydziały obwodowe, przy dodatkowym zastrzeżeniu - nominacje członków pochodzących z wyboru wymagały zatwierdzenia przez nadprezydenta prowincji; po dwukrotnym odrzuceniu kandydatur mógł on samodzielnie nominować członków wydziału.

Wydział obwodowy zajmował się jednak nie tylko sprawami spornymi, ale i pozostawał właściwą instancją administracyjną w postępowaniu uchwałowym (Beschlussverfahren). Ustawa o ogólnej administracji kraju i ustawa o właściwości władz rozróżniały bowiem dwa typy działania kontrolnego władz administracyjnych. Pierwszy to działanie w postępowaniu sporno-administracyjnym, stosowane w przypadkach, gdy ustawa stanowiła o rozstrzygnięciu (Entscheidung) lub skardze (Klage). Drugi typ to niesporne postępowanie uchwałowe, znajdujące zastosowanie, gdy w przepisach ustawy pojawiało się sformułowanie: [organ] ,uchwala” (beschliesst), przy czym, paradoksalnie, w obu trybach działać mogły te same organy. Początkowo sądy obwodowe orzekały w sprawach spornych, a rady obwodowe w postępowaniu uchwałowym, jednak, o czym już wspomniano, w 1883 r. nastąpiło skumulowanie tych kompetencji w nowo powołanym wydziale obwodowym. Zatem ten ostatni działał w obu postępowaniach, raz jako sąd (wówczas kierował nim wspomniany dyrektor sądu), innym razem jako organ administracji (pod przewodnictwem prezesa rejencji). Jasne więc, że brak w takiej konstelacji jakichkolwiek szerszych gwarancji niezawisłości, choć gwoli ścisłości wspomnieć należy, że członkowie sądu-wydziału podlegali ustawie dyscyplinarnej dla sędziów sądów powszechnych, nie zaś urzędników państwowych.

Dualizm ten wpływał też na kształt postępowania odwoławczego i decydował o zawiłym charakterze rozwiązań przyjętych w zakresie trybu instancyjnego. Jeśli wydział obwodowy działał jako instancja administracyjna i podejmował decyzje w drodze postępowania uchwałowego, właściwą instancję odwoławczą stanowiła rada prowincjonalna (Provinzialrat), tj. organ na najwyższym szczeblu podziału terytorialnego - prowincji.

System wieńczył powołany w 1875 r. Najwyższy Sąd Administracyjny (Oberverwaltungsgericht - dalej: OVG) w Berlinie, o składzie wyłącznie zawodowym: złożonym w połowie z sędziów i w połowie mianowanych urzęd-

11 Jeden z nich musiał mieć wymagane kwalifikacje sędziowskie, drugi zaś uprawnienia do objęcia wyższego urzędu w administracji (na mocy $\S 9$ ustawy o ustroju sądów...). 
ników, uprawnionych do objęcia wyższych stanowisk administracyjnych. Mianowani byli dożywotnio przez króla, na wniosek Staatsministerium. Sąd ten mógł wyjątkowo działać jako sąd pierwszej instancji w sprawach wymienionych enumeratywnie w ustawach ${ }^{12}$. Jako sąd II instancji rozpatrywał odwołania (Berufung) od orzeczeń wydanych w I instancji przez obwodowe sądy administracyjne (wydziały obwodowe), zaś w III instancji - rewizje od wydanych przez sądy obwodowe w II instancji wyroków ostatecznych (Endurtheile), o ile nie były prawomocne na mocy przepisów szczególnych. W wyjątkowych sprawach ustawa kompetencyjna upoważniała do wniesienia rewizji do OVG z pominięciem odwołania ${ }^{13}$. OVG rozpatrywał też skargi na prowadzenie postępowania w sądach obwodowych i wykonywał nadzór administracyjny nad sądami niższych instancji. Dla podjęcia uchwały wymagane było quorum 5 sędziów. Kwestie szczegółowe regulował regulamin z 27 grudnia 1876 r. $^{14}$, nadany przez Staatsministerium ${ }^{15}$.

Pierwszym prezesem OVG został Paul Persius, który pełnił tę funkcję aż do 1902 r. Ostatnim przed wojną prezesem sądu, pełniącym tę funkcję w latach 1908-1914, był znany doskonale polskiej mniejszości dr Rudolf von Bitter, zasłużony pruski urzędnik, dawniej landrat w powiecie Waldenburg na Śląsku (Wałbrzych), następnie prezes rejencji opolskiej i nadprezydent prowincji poznańskiej.

Ustawodawca pruski nie odważył się na udzielenie sądownictwu administracyjnemu pełnych gwarancji niezależności. Przyjęto złożony model, który w pierwszej instancji był związany z organem quasi-samorządowym, tylko w części wybieranym przez Kreistag i do tego kierowanym przez landrata w Poznańskiem, warto przypomnieć, pochodzącym z nominacji, a nie z wyboru Kreistagu. Zresztą król nie przestrzegał przepisów także w Prusach Za-

12 Początkowo były to: ustawa o sądach administracyjnych z 3 lipca 1875 r. (§ 12, 21, 22, 24, 25, 83); ustawa kompetencyjnej z 26 czerwca 1876 r. $(\$ 30,34,37,38,61,70,143,161,169)$; ordynacja prowincjonalna dla prowincji Preußen, Brandenburg... z 29 czerwca 1875 r. (§ 1, 3, 4, $24,48,62,67,118,121,128)$; ustawa wprowadzająca $\S 5$ i 6 ustawy z 30 kwietnia 1873 r. o dotacjach dla związków prowincjonalnych i powiatowych z 8 czerwca 1875 r. - Gesetz betreffend die Ausführung der $\$ 5$ und 6 des Gesetzes vom 30. April 1873 wegen der Dotation der Provinzial- und Kreisverbände (GS. S. 497, § 18) r.; ustawa o ustroju kościołów ewangelickich dla ośmiu starszych prowincji monarchii z 3 czerwca 1876 r. - Gesetz betreffend die evangeliche Kirchenverfassung in den acht alten Provinzen der Monarchie (GS, s. 125, art. 27); ustawa o nadzorze państwowym nad zarządem majątkiem w diecezjach katolickich z 7 czerwca 1976 r. - Gesetz über die Aufsichtsrechte des Staates bei der Vermögenverwaltung in den katholischen Diözesen (GS. S. 149, § 6), ustawa o zarządzie zagajników należących do gmin i zakładów publicznych w prowincjach Preußen, Brandenburg, Pommern, Posen, Schlesien und Sachsen z 14 sierpnia 1876 r. - Gesetz, betreffend die Verwaltung der den Gemeinden und öffentlichen Anstalten gehörigen Holzungen in den Provinzen Preußen... (GS. S. 373, § 11, 13).

$13 \S 63,93,130-132,147,164$ ustawy kompetencyjnej.

14 Ministerial-blatt der inneren Verwaltung 1876, s. 9.

15 Zob. szerzej Entscheidungen des Königlichen Preußischen Oberverwaltungsgerichts, t. 1, s. 1-7. 
chodnich $^{16}$. Rudolf von Gneist głęboko wierzył w swoistą misję czynnika obywatelskiego i przedkładał go nad profesjonalizm sędziów zawodowych, jednakże w konkretnym pruskim modelu czynnik ów doznał istotnych ograniczeń. W I instancji z pewnością podatny pozostawał na wpływy administracji rządowej w osobie dysponującego szerokimi kompetencjami landrata. Jeszcze dziwniejszy charakter miała II instancja, częściowo wyłoniona przez samorządowy wydział prowincjonalny, a częściowo mianowana. Tu z kolei bliskie związki z prezesem rejencji nie gwarantowały samodzielności. Na taką mógł się zdobyć dopiero OVG w Berlinie i to jego orzeczenia władze administracyjne ,polskich” prowincji państwa pruskiego bacznie śledziły.

III. System opierał się w sferze kompetencji przedmiotowej na metodzie enumeracji, uznanej z pewnością za bezpieczniejszą przez parlamentarnych konserwatystów. Poszczególne ustawy wymieniały podległe jurysdykcji administracyjnej kwestie łącznie w setkach paragrafów ${ }^{17}$. Ustawy wskazywały także explicite, w jakich sprawach właściwy jest dany sąd, tj. wydział powiatowy czy też wydział obwodowy.

Wyliczenie takie naturalnie nie mogło objąć wszelkich spornych spraw administracyjnych. Wyjątek od systemu wyliczenia stanowiły skargi na zarządzenia policyjne (Verwaltungsklagen gegen polizeiliche Verfügungen), ujęte - co należy szczególnie podkreślić - w klauzuli generalnej ${ }^{18}$. Na bardzo szeroko rozumiane zarządzenie policyjne przysługiwała skarga do wydziału powiatowego jako sądu administracyjnego (co wszczynało postępowanie sporne), bądź, według uznania skarżącego, zażalenie składane na ręce landrata w drodze postępowania uchwałowego do tegoż wydziału jako władzy administracyjnej.

Sądy pruskie w zasadzie orzekały a posteriori. Nie dopuszczano generalnie powództw ustalających (Feststellungsklagen), niemniej w szczególnych przypadkach, tzw. pierwotnych spornych spraw administracyjnych (ursprüngliche Verwaltungsstreitsachen), sądy w sytuacji braku aktu administracyjnego decydowały także merytorycznie ${ }^{19}$. Nie ulega wątpliwości, że pruskie sądownictwo administracyjne z pewnością zasłużyło na miana „labiryntu”,

16 Jeszcze w 1860 r. sejmik powiatu brodnickiego przedstawił trzy kandydatury na stanowisko landrata, trzech Polaków, znanych lokalnych działaczy. Król nie zatwierdził żadnej z kandydatur, ostatecznie landratem został Niemiec. Por. C. Obracht-Prondzyński, Ku samorządnemu Pomorzu. Szkice o ksztaltowaniu się ładu demokratycznego, Gdańsk 2002, s. 18.

${ }^{17}$ Skrupulatni juryści pruscy próbowali nad tym zjawiskiem zapanować, zestawiając w odrębnych wydawnictwach tę karkołomną podstawę prawną. Por. wydawnictwo Biura OVG: Die Zuständigkeit der Preußischen Verwaltungsgerichts und Beschlußbehörden. Nach den Gesetzen und den dazu ergangenen Ausführungsbestimmungen, Berlin 1911.

${ }^{18}$ Zob. rozdz. IV ww. ust. o ogólnej administracji kraju z 1883 r.

19 Por. J. Langrod, Zarys sądownictwa administracyjnego, Warszawa 1925, s. 140. 
„kazuistyki pozbawionej zasad”, „hipertrofii środków prawnych”, „różnobarwności” (,Buntscheckigkeit”), jakimi obdarzali je komentatorzy ${ }^{20}$.

Pewnym wyznacznikiem przedmiotowej kategoryzacji spraw, jaką przyjmował OVG, mogą być urzędowe i półurzędowe przeglądy orzecznictwa tego sądu ${ }^{21}$. Wyraźnie dają się tu wyróżnić płaszczyzny prawa administracyjnego ustrojowego, materialnego i procesowego.

W pierwszej kolejności wyodrębniał OVG sprawy organów jednostek podziału terytorialnego. W ramach spraw prowincji odnosił się do uprawnień związku prowincjonalnego, sejmu prowincjonalnego, wydziału powiatowego, urzędników prowincji, danin prowincjonalnych, przymusowej etatyzacji. W zakresie właściwości powiatów badał uprawnienia związku powiatowego, zobowiązania członków powiatu do pełnienia funkcji honorowych, kwestie związane z landratem, sejmikiem powiatowym (szczegółowe kwestie związane z wyborami do Kreistagu, jego zwołanie, posiedzenia i prowadzenie działań), wydziałem powiatowym, daniny powiatowe, sprawy nadzoru. Przedmiotem orzecznictwa w analogicznym zakresie stały się sprawy gmin miejskich (prawa miejskie, kwestie okręgu miejskiego, prawo wyborcze, w tym postępowanie, do władz miejskich, uchwały rady miejskiej, status prawny burmistrza, magistratu, deputowanych, urzędników miejskich, zakłady miejskie, budżet miejski, nadzór nad miastami). Orzecznictwo wobec gmin koncentrowało się na majątku gminnym i obciążeniach gminy - takich spraw było stosunkowo dużo. W węższym stopniu badano stosunki ustrojowe gmin wiejskich i obszarów dworskich (prawo swojszczyzny, wybory gminne, uchwały gminne, zarząd gminny, związki gminne). Niewiele orzeczeń odnosiło się do administracji wójtostw (Amtsverband, Amtsbezirk ${ }^{22}$ ) i wójtów, ich naczelników (Amtsvorsteher).

${ }^{20}$ Przywołuje je M. Ibler, Rechtspflegender Rechtsschutz im Verwaltungsrecht. Zur Kontrolldichte bei wertenden Behördenentscheidungen - vom Preußischen Oberverwaltungsgericht bis zum modernen Gerichtsschutz im Prüfungsrecht, Tübingen 1999, s. 204.

${ }^{21}$ Jako pierwsze ukazały się tomy Entscheidungen des Preußischen Oberverwaltungsgerichts [dalej: Entscheidungen des Pr. OVG], pod redakcją radców OVG von Jebensa i von Menerena. I tom ukazał się w Berlinie w 1877 r., w 1941 r. okoliczności wojenne przerwały wydawnictwo po wydaniu 106 tomów. Po ukazaniu się 29 tomów zadecydowano o potrzebie równoległego przygotowania systematycznego zestawienia kluczowych orzeczeń. Zob. Die Rechtsprechung des Königlichen Preußischen Oberverwaltungsgerichts in systematischer Darstellung, hrsg. von B. v. Kamptz, $\mathrm{Ph}$. Freytag, S. Genzmer, G. Barre, A. Germershausen, M. Dirksen, [dalej: Rechtsprechung des OVG]. Wydawnictwo, przygotowane na przestrzeni lat 1897-1912, objęło cztery tomy główne i pięć tomów uzupełniających. Zbiór ma półurzędowy charakter - w gronie redaktorów znaleźli się sędziowie OVG, prezesi sądów administracyjnych, prezes sądu rejonowego i radca rejencji. Orzeczenia publikowano też w Preußisches Verwaltungsblatt. Wochenschrift für Verwaltung und Verwaltungsrechtspflege in Preußen [dalej: PrVB1.], ukazującym się w latach 1879-1928.

22 Pojęcie thumaczone w języku polskim jako „wójtostwa”, „okręgi wójtowskie” czy „urzędy okręgowe". Twory te powołano do życia na mocy ordynacji powiatowej z 1872 r. i na ich czele postawiono wójtów (Amtsvorsteher; tłumaczony także jako naczelnik okręgu wójtowskiego czy urzę- 
W zakresie administracyjnego prawa materialnego ilościowo na pierwszy plan wysuwają się sprawy, związane z zaskarżeniem działań administracji w zakresie administracji budowlanej. Rozstrzygnięcia mają najrozmaitszy przedmiot - od pojęcia dróg publicznych, przez zasady użytkowania dróg publicznych, zakres obciążeń związanych z budową dróg, oczyszczanie dróg, prawa osób trzecich na drogach publicznych, zobowiązania do budowy dróg w obszarach dworskich i gminach, budowy szos, obowiązki fiskusa w zakresie wspierania budowy dróg lokalnych, właściwość organów w zakresie administracji drogowej, postępowanie w sprawach budowy dróg, po wytyczanie nowych dróg i zmiany statusu dróg z prywatnych na publiczne. W ramach obfitego orzecznictwa, dotyczącego obowiązku budowy dróg, OVG przyjmował kryterium miejscowe, segregując orzeczenia wedle poszczególnych prowincji.

Do kategorii kontroli stosowania prawa materialnego należą też stosunkowo wąsko reprezentowane sprawy wyznań, gmin żydowskich, zaopatrzenia ubogich. Bogate jest orzecznictwo związane ze szkolnictwem. Wśród tych ostatnich odnosił się OVG do zagadnień ogólnych: pojęcia szkoły, związku szkolnego, obwodu szkolnego, lekcji, planów nauczania, obowiązku szkolnego, majątku szkolnego, zarządu szkoły. Wobec nauczycieli badał OVG sporne kwestie związane z ich statusem prawnym, dochodami, a także odnoszące się do nich przepisy administracyjno-karne. Wśród badanych kwestii szczegółowych znalazły się też sprawy nadzoru szkolnego i właściwości organów w tym zakresie. Często wypowiadał się OVG na temat sporów związanych z pokrywaniem kosztów utrzymania szkoły. W późniejszym okresie szczegółowe kwestie materialne w zakresie szkolnictwa kategoryzował OVG według prowincji, z uwagi na urozmaiconą podstawę prawną.

Kolejne kategorie spraw dotyczą administracji wodnej, rybackiej i ochrony lasów. W zakresie budzącej wiele konfliktów policji łowieckiej OVG zajmował się takimi kwestiami, jak: zakres prawa łowieckiego, tworzenie obwodów łowieckich, zawieranie umów w sprawie dzierżaw terenów łowieckich (Jagdpachtverträge), właściwość i uprawnienia organów administracji łowieckiej, udzielanie i odbieranie uprawnień łowieckich, postępowanie sporne w sprawach łowieckich, roszczenia o wyrównanie szkód w dzikim dobrostanie (Wildschaden).

Wiele spraw wynika z ordynacji przemysłowej. Osobno OVG klasyfikował sprawy z zakresu właściwości izb handlowych, korporacji kupieckich i giełd oraz izb rolnych (Landwirtschaftskammer). Inną kategorię stanowią sprawy ubezpieczeń społecznych: zdrowotnych i od nieszczęśliwych wypadków. Szeroko odnosił się OVG do problemów administracji budowlanej: od

du okręgowego). Nie dotyczyło to prowincji poznańskiej, gdzie na mocy nadal obowiązujących przepisów z 1824 r. działali komisarze obwodowi czy też dystryktowi (Distriktkommissaren). 
kategorii podstawy prawnej, tj. charakteru przepisów w zakresie policji budowlanej, ich wymiaru temporalnego, zwolnień z postanowień ordynacji administracji budowlanej, przez pojęcie budowy, pozwoleń na budowę, uprawnień władz nadzorczych do wkraczania na naruszającą przepisy budowę, zobowiązania właściciela w zakresie utrzymania nieruchomości, ograniczenia wynikłe z potrzeb ochrony zdrowia i przeciwogniowej, ruchu publicznego, po właściwość organów i postępowanie w sprawach budowlanych. Właściwość OVG dotyczyła też spraw kolejek torowych i prywatnych kolejek dojazdowych. Kolejna kategoria to osadnictwo. Niewiele spraw dotyczyło stanu cywilnego i kwestii obywatelstwa.

Osobno OVG kategoryzował i traktował w szerszej perspektywie sprawy związane z rozporządzeniami policyjnymi i aktami wykonawczymi w zakresie prawa administracyjnego. Wypowiadał się na temat charakteru rozporządzeń policyjnych, ogólno-administracyjnych i karnych, jako podstaw działania administracji oraz ich zaskarżalności. Interpretował szeroko kluczowe pojęcia, np. ,porządku”, ,porządku publicznego”, „szkodzenia dobru publicznemu”, sięgając nie tylko do źródeł ustawowych i orzecznictwa sądów, ale i projektów ustawodawczych, często o historycznym charakterze (dotyczących ALR czy projektu Allgemeines Gesetzbuch für die Preussischen Staaten) ${ }^{23}$.

Sąd badał właściwość organów policyjnych (administracyjnych) i jej przekroczenia w rozmaitych kontekstach (np. zachowania porządku i bezpieczeństwa publicznego, nadużycia uprawnień w zakresie stosowania środków przymusu). Wśród ogólnych rozporządzeń policyjnych wyodrębnił m.in. te odnoszące się do szczególnych obszarów administracji, w tym do prawa zrzeszeń i zgromadzeń, definiując przedmiotowe pojęcia i precyzując uprawnienia policji w zakresie ich działalności.

Przedmiotem orzecznictwa OVG były też sprawy dyscyplinarne (czyny karalne, występki, przebieg postępowania dyscyplinarnego). Wreszcie obszerną kategorię spraw stanowią sprawy dotyczące postępowania sporno-administracyjnego. OVG badał przepisy ogólne - stosunek postępowania sporno-administracyjnego do postępowania procesowego cywilnego i do prawa prywatnego, status prawny sądów administracyjnych i ich właściwość miejscową, obsadę sądu, problem wykluczenia sędziego, legitymację stron postępowania, terminy. Interpretował też przepisy regulujące tok postępowania I instancji, postępowań kolejnych instancji, wznowienie postępowania i koszty.

IV. Po wstrząsach Wiosny Ludów państwo pruskie otrzymało ostatecznie konstytucję w roku $1850^{24}$. To typowa ustawa zasadnicza, oparta na „Monarchisches Prinzip", jakich wiele objawiło się w epoce reakcji jako klony fran-

${ }^{23}$ Orzeczenie OVG z 14 czerwca 1882 (Entscheidungen des OVG, t. 9, s. 353, Die Rechtsprechung des OVG, Bd. IV 1898, s.744-758).

24 Verfassungsurkunde für den Preussischen Staat vom 31 Januar 1850 (GS, s. 17). 
cuskiej Charte Constitutionelle. Konstytucja ta zawierała rozdział poświęcony prawom „Prusaków”. Do konstytucyjnych praw podstawowych (w wersji po rewizji) zaliczała: równość wobec ustawy (art. 4), wolność osoby (art. 5), nienaruszalność mieszkania (art. 6), wolność wyznania (art. 12), wolność słowa (art. 27, w art. $28 \S 2$ formalnie zakazano wprowadzania cenzury, jednak dopuszczono wprowadzenie ,innych ograniczeń wolności prasy” na mocy ustawy), wolność zgromadzeń (art. 29) i stowarzyszeń (art. 30), gwarancję własności (art. 9), gwarancje ochrony prawnej (art. 7, obejmujący w zd. drugim także zakaz powoływania sądów nadzwyczajnych, art. 8). W art. 20 ustanowiono wolność badań i nauki. Sądownictwu zagwarantowano konstytucyjnie niezawisłość (art. 86). Art. 96 ustanawiał rozdział administracji i sądownictwa, co gwarantować miał także powołany już w 1847 r. do rozstrzygania sporów kompetencyjnych trybuna ${ }^{25}$. Konstytucja nie ograniczała się do praw wolnościowych, ale nadawała także ramowe ordynacje ${ }^{26}$ trzem instytucjom - uznawanym przez państwo pruskie, przekonane o ich szczególnej roli wychowawczej, za publiczne - kościołowi, szkole i armii, ustanawiając zarazem wobec dwóch ostatnich powszechne obowiązki: szkolny i służby wojskowej. Błędem jest zatem uproszczone przyjmowanie, że wszelkie gwarancje instytucjonalne wprowadziła dopiero konstytucja weimarska ${ }^{27}$.

Jednakże charakter prawny norm zawierających prawa podstawowe budził rozległe wątpliwości. Paul Laband czy Otto Mayer odmawiali prawom podstawowym znaczenia podmiotowego, jako że według nich poddanemu nie mogło przysługiwać prawo ,przeciwko państwu”. W gruncie rzeczy nauka dość powszechnie traktowała regulacje konstytucji w zakresie praw podstawowych wyłącznie jako wskazówki dla przyszłego ustawodawstwa zwykłego. Ustawy zaś pruskie pozostawały przez pierwsze dziesięciolecia obowiązywania konstytucji w sprzeczności z konstytucją, niejednokrotnie traktując wolności w ograniczony sposób i nie dopuszczając wyjątków (prawo wyznaniowe, regulacje swobody przemieszczania się) ${ }^{28}$.

Co należy szczególnie podkreślić, przepisy konstytucyjne w praktyce nie były traktowane jako regulacje najwyższej rangi. Sama konstytucja pruska, zdaniem wielu komentatorów, zawierała w art. 106 regulację uniemożliwiającą badanie konstytucyjności wydanych zgodnie z procedurą legislacyjną ustaw i rozporządzeń (,....są wiążące, jeśli są opublikowane w przewidzianej

${ }^{25}$ Gerichtshof zur Entscheidung der Kompetenzkonflikte.

${ }^{26}$ Nazwane później przez C. Schmitta „instytucjonalnymi gwarancjami”. Za: E.R. Huber, Deutsche Verfassungsgeschichte seit 1789. Bd. III: Bismarck und das Reich, 3. überarb. Aufl., Stuttgart 1988, s. 102.

27 Przeciwko tej powielanej tezie występuje chociażby E.R. Huber, Deutsche Verfassungsgeschichte..., Bd. III, s. 102. Por. szerzej na temat praw podstawowych: ibidem, s. 100-128.

${ }^{28}$ U. Scheuner, Die rechtliche Tragweite der Grundrechte in der deutschen Verfassungsentwicklung des 19. Jahrhunderts, [w:] Festschrift für Ernst Rudolf Huber. Zum 70. Geburtstag am 8. Juni 1973, hrsg. von E. Forsthoff, W. Weber, F. Wieacker, Göttingen 1973, s. 156-158. 
ustawą formie"). Ihering i von Gneist występowali na rzecz prymatu norm konstytucyjnych podczas zjazdów prawniczych w 1862 i 1863 r., jednak większość słuchaczy odrzucała tę koncepcję, akceptując jedynie prawo sądu do kontroli przebiegu procesu ustawodawczego i - ewentualnie - zgodności rozporządzeń z konstytucją i ustawami, o ile nie wykluczała tego sama konstytucja ${ }^{29}$. Prawa badania konstytucyjności norm ustawowych odmawiali przedstawiciele nauki sądom administracyjnym; te nie miały służyć ochronie praw podstawowych ${ }^{30}$. Wreszcie, o ile w ogóle prawa te miały mieć znaczenie normatywne, to wyłącznie wobec obywateli Prus. Wszystkie te czynniki przesądzały o słabości praktycznego obowiązywania konstytucyjnych praw podstawowych.

To dopiero ustawodawstwo zwykłe, w tym kluczowe ustawy Rzeszy, nadało mglistym kształtom pruskich praw podstawowych konkretny charakter i umożliwiło ochronę prawną jednostek. Georg Jellinek twierdził, że: „In Wahrheit ist im Deutschen Reiche das Maß öffentlicher Rechte des Individuums viel größer als in manchen Staaten mit verfassungsmäßig katalogisierten Grundrechten" 31 .

Dieter Grimm uznawał nawet, że koncepcja praw podstawowych straciła znaczenie polityczne dla mieszczaństwa w dobie cesarstwa. Państwo policyjne stało się - według niego - przeszłością; mieszczańskiemu państwu prawa nie groziło już nic z jego strony, a polityczna potrzeba wolności uległa redukcji ${ }^{32}$.

Oczywiste jest jednak, że gwarancje praw obywatelskich, praw wolnościowych nabierają szczególnego znaczenia właśnie tam, gdzie wykonywanie tych praw jest zagrożone. Wobec braku konstytucyjnej sankcji naruszeń ochrony konstytucyjnych praw podmiotowych, sprowadzenie katalogu tych praw do ram ustaw materialnych stało się realnym problemem. Ich treść, a przede wszystkim sposób realizacji dowodzi, że państwo policyjne miało się bardzo dobrze - w praktyce „zarządzanie” prawami wolnościowymi spoczęło bowiem w rękach organów policyjnych. To one decydowały o faktycznym zakresie stosowania praw i ten proces nadzorowały, mając do dyspozycji wachlarz możliwości, a przecież długo w XIX w. obowiązywała zasada, że przeciwko zarządzeniom policyjnym nie przysługuje odwołanie. Prasa, stowarzyszenia czy organizacja zgromadzeń znalazły się pod ścisłą admini-

${ }^{29}$ Ibidem, s. 156-157.

${ }^{30}$ F. Giese, Die Grundrechte, Tübingen 1905, s. 74.

31 „W rzeczywistości wymiar praw publicznych jednostki jest w Rzeszy Niemieckiej o wiele większy niż w niektórych krajach, w których prawa podstawowe skatalogowano w konstytucji" (tłum. wł.). Cyt. za: G. Jellinek, Die Erklärung der Menchen- und Bürgerrechte. Ein Beitrag zur modernen Verfassungsgeschichte, 3. Aufl., München-Leipzig 1919, s. 4.

${ }^{32}$ D. Grimm, Die Entwicklung der Grundrechtstheorie in der deutschen Staatsrechtslehre des 19. Jahrhunderts, [w:] Grund- und Freiheitsrechte von der ständischen zur spätbürgerlichen Gesellschaft, hrsg. von G. Birtsch, Göttingen 1987, s. 265. 
stracyjno-policyjną kuratelą. Odwołując się do Michaela Kotulli: „Behördenwillkür bei der Regelung des Einzelfalles wähnte man nicht zuletzt deshalb ausgeschlossen, weil davonausgegangen wurde, da $\beta$ die Verwaltung den ihr einmal gesetzlich abgesteckten Handlungsrahmen respektierte bzw. Überschreitungen desselben selbst korrigierte" 33 .

Zasadnie można zauważyć, że państwo pruskie, a następnie w jeszcze większym stopniu Rzesza, różnicowało status prawny swoich obywateli w związku z ich narodowością, wprowadzając regulacje uzależniające pewne uprawnienia od np. kwestii języka. Praw przyrzeczonych w odezwie z 15 maja 1815 r. przez Fryderyka Wilhelma III - który przyjął tytuł Wielkiego Księcia Poznańskiego, obiecując pewną odrębność organizacyjną ziemiom polskim nie dotrzymano. Monarcha obiecywał formalnie zachowanie „narodowości”, „udział w konstytucji”, własną ustawę prowincjonalną, zachowanie języka ojczystego w czynnościach publicznych. Jednocześnie tajne ustalenia w Wiedniu już przesądziły o tym, że Poznańskie stanie się ,integralną częścią monarchii pruskiej i ma być wedle tego urządzone. Narodowość mieszkańców szanować należy o tyle, o ile da to się z głównym celem pogodzić"34.

Na przestrzeni XIX w. wyraźnie zauważalne jest, w jakich okresach mniejszości narodowe czy etniczne (polska, litewska, alzacka oraz w nieco mniejszym stopniu, zwłaszcza w praktyce, duńska) szczególnie narażone były na germanizującą presję ze strony organów administracji, przyjmującą postać ewolucji przepisów związanych z językiem (używanym w celach urzędowych, w szkole, w kościele, podczas zgromadzeń publicznych) czy kolonizacji gospodarczej. Generalnie ten kierunek polityki państwowej, wspomagany przez działalność prywatnych czy półprywatnych stowarzyszeń przybierał z biegiem czasu na sile. Przerywany był wprawdzie epizodami względnej liberalizacji Polenpolitik, idącej w parze ze składaniem niespełnionych najczęściej obietnic, by pod koniec XIX w. przyjąć bezwzględny, rygorystyczny charakter zaplanowanego i wszechstronnego kursu, prowadzącego do licznych niepokojów społecznych. Konsekwencje procesu gnieźnieńskiego, skazującego oskarżonych po wypadkach we Wrześni, odbiły się szerokim echem nie tylko w Prusach i sąsiadującym Królestwie Kongresowym, ale również za granicą ${ }^{35}$.

33 „Wykluczano samowolę władz przy regulacji poszczególnych przypadków, wychodząc z błędnego założenia, że administracja przestrzegała zakresu działania ustanowionego na drodze ustawowej a ewentualne przekroczenia tegoż sama korygowała" (tłum. wł.). M. Kotulla, Die konstitutionellen Grundrechte in der Rechtsprechung des Preußischen Oberverwaltungsgerichts bis 1918, [w:] Vorträge zur Justizforschung. Geschichte und Theorie, hrsg. von H. Mohhaupt, D. Simon, Bd. 2.: Rechtsprechung. Materialien und Studien, Veröffentlichungen des Max-Planck-Instituts für Europäische Rechtsgeschichte, Frankfurt am Main, Bd. 7, 1993, s. 336.

${ }^{34}$ Fragment protokołu konferencji ministerialnej (7 IV 1815, Wiedeń) cytuje J. Kozłowski, Wielkopolska pod zaborem pruskim w latach 1815-1918, Poznań 2006, s. 56.

35 Literatura tych wydarzeń jest bogata, choć najważniejsze archiwalia niestety przepadły bezpowrotnie wraz z pożarem poznańskiego Archiwum Państwowego. Tytułem przykładu por. 
Należy też mieć na uwadze, że ostatecznie w 1871 r. pruscy obywatele, należący do mniejszości narodowych, zostali obywatelami Rzeszy. Polacy nie przyjęli z radością tego faktu. „Wir wollen, meine Herren, bis Gott anders über uns bestimmt hat, unter preußischen Herrschaft bleiben, aber den Deutschen Reich wollen wir nicht einverlebt sein" 36 - głosił polski poseł Krzyżanowski w Reichstagu 1 kwietnia 1871 r. Wielu badaczy, zwłaszcza niemieckich, podkreśla, że o ile państwo pruskie nie akcentowało jeszcze swego narodowościowego charakteru, o tyle nabrała go II Rzesza i wprost skonfrontowała $\mathrm{z}$ polskim interesem narodowym ${ }^{37}$.

Frankfurckie Zgromadzenie Narodowe proponowało szeroki katalog stosowalnych bezpośrednio praw i wolności, jednakże, ze zrozumiałych względów, w jego ślady nie poszli ani twórcy konstytucji Związku Północno-Niemieckiego, ani II Rzeszy. Konstytucja Rzeszy nie zawierała katalogu praw, nadmieniała jedynie, że obywatelom państw związkowych z tytułu powszechnego obywatelstwa Rzeszy (ściślej w tekście mowa o „gemeinsames Indigenat"), ustanowionego na mocy art. 3, w innych krajach związkowych przysługują analogiczne jak krajowcom, prawa dotyczące zamieszkania, zawodu, dostępu do urzędów, nabywania ziemi, domagania się praw obywatelskich (,Erlangung des Staatsbürgerrechtes”).

Przepisy regulujące prawa obywatelskie pojawiały się jednak coraz częściej w ustawach. Autorzy dokonują dość zgodnego wyliczenia, wymieniając m.in. ustawę o swobodzie przemieszczania się (Freizügigkeitgesetz z 1 listopada 1867 r.); ustawę o równouprawnieniu wyznań (Gesetz betreffend Gleichberechtigung der Konfessionen in bürgerlicher und staatsbürgerlicher Hinsicht z 3 lipca 1869 r.); ordynację przemysłową (Gewerbeordnung z 21 czerwca 1869 r., Reichsgewerbeordnung), ustawę prasową (Reichspressegesetz), ustawę związkową (Reichsvereingesetz z 19 kwietnia 1908 r.), ustawę pocztową (Gesetz über das Postwesen z 28 października 1871 r.), ustawę o ustroju sądów (Gerichtsverfassungsgesetz z 27 stycznia 1877 r.), procedurę karną (Strafprozeßordnung z 1 lutego 1877 r.) ${ }^{38}$.

Z. Grot, Sprawa wrzesińska, „Przegląd Zachodni”, R. 7 (1951), nr 9/10, s. 72-131; ze strony niemieckiej R. Korth, Die preussische Schulpolitik und die polnischen Schulstreiks. Ein Beitrag zur polnischen Polenpolitik der Ära Bülow, Würzburg 1963, s. 82-115. Praca A.J. Eimera, Proces wrzesiński w świetle dokumentów sqadowych, Poznań 1927, jest bardzo trudno dostępna.

36 „Chcielibyśmy, moi panowie, dopóki Bóg nie postanowi o nas inaczej, pozostać pod panowaniem pruskim, ale nie chcemy być wcieleni do Rzeszy Niemieckiej” (tłum. własne). Cyt. za: T. Schieder, Das Deutsche Kaiserreich von 1871 als Nationalstaat, Köln-Opladen 1961, s. 20.

${ }^{37}$ E.R. Huber, Deutsche Verfassungsgeschichte seit 1789, Bd IV.: Struktur und Krisen des Kaiserreiches, Stuttgart 1969, s. 482 i n.

${ }^{38}$ Tak i szerzej E.R. Huber, Grundrechte im Bismarkschen Reichsystem, [w:] H. Ehmke, J.H. Kaiser, W.A. Kewenig, K.M. Meessen, W. Rüfner, Festschrift für Ulrich Scheuer zum 70. Geburtstag, Berlin 1973, s. 169. 
V. Pytanie tytułowe brzmi zatem właściwie: czy sądy, w tym powstałe w ostatnich dziesięcioleciach XIX w. administracyjne, mogły stanowić barierę dla działań administracji, która idąc z duchem germanizującej polityki płynącej z Berlina nadużywała swoich uprawnień. Sądy administracyjne nie miały wyłącznej właściwości w wielu kluczowych dla swobód obywatelskich sprawach. Najważniejsze dla interesów polskich sprawy sądowe miały charakter administracyjno-karny, z tytułu przekroczenia przepisów karnych ustaw administracyjnych lub niewykonania zarządzeń policyjnych w tym zakresie. Sprawy te trafiały do wydziałów karnych sądów powszechnych, według trybu instancyjnego: sąd przysięgłych (Schöffengericht) - apelacja do sądu rejonowego (Landgericht); gdy Landgericht był I instancją, tj. w poważniejszych sprawach, sądzonych od razu przez zawodowy skład - rewizja do Oberlandesgericht. Najsłynniejsze procesy, dotyczące wolności prasy w językach narodowych, cenzury, szkolnictwa, toczyły się więc - ze zmiennym dla oskarżonych szczęściem - głównie przed sądami powszechnymi.

Do sądów administracyjnych można było jednak wnosić skargi o przekroczenie właściwości organów administracyjnych - do regulowania pewnych płaszczyzn administracyjnych w drodze aktów miejscowych i organów policyjnych - do wydawania rozporządzeń policyjnych na podstawie ustaw i aktów prezesów rejencji. Kontroli podlegał też zakres tych policyjnych regulacji.

Nie jest łatwym zadaniem zweryfikować wiarygodność sądów administracyjnych jako gwarantów praw podmiotowych, przysługujących także mniejszości polskiej. Zasób zachowanych akt wyższych sądów administracyjnych prowincji poznańskiej i zachodniopruskiej nie rozkłada się równomiernie ${ }^{39}$, a przeprowadzona kwerenda nie upoważnia do uogólniających wniosków. Z kolei przywołane zbiory orzeczeń OVG obejmują orzecznictwo całego kraju, tylko w kilku działach zestawione terytorialnie i ich zbadanie, według klucza terytorialnego ukrytego w zwięzłym opisie stanu faktycznego, wymaga benedyktyńskiej pracy. Odpisy wybranych akt procesowych zachowały się w aktach rejencji poznańskiej czy bydgoskiej w GStaPK.

Wybrane kwestie zostały opracowane w literaturze, prace współczesne wydarzeniom nie są jednak wolne od obciążeń politycznych. $Z$ kolei orzecz-

39 W AP Poznań zespół akt Okręgowy Sąd Administracyjny w Poznaniu (53/293/0) obejmuje ponad tysiąc dwieście jednostek, dotyczących wyłącznie okresu od 1890 r. Zespół akt Wydziału Obwodowego Rejencji w Bydgoszczy (AP Bydgoszcz 6/173/0) liczy 62 jednostki, zaś w aktach gdańskiego odpowiednika zachowały się akta wyłącznie jednej sprawy spornej, w postępowaniu administracyjnym w sprawie zwrotu kosztów opieki z 1918 r. (AP Gdańsk, 53/293/0). Także kwerenda w Geheimes Staatsarchiv Preussischer Kulturbesitz [dalej: GStaPK] w Berlin-Dahlem dowodzi zróżnicowania zachowanych źródeł. Z akt Wydziału Obwodowego rejencji gdańskiej zachowały się akta jednej sprawy spornej dotyczącej kosztów budowy drogi (XIV HA Rep. 182 Bezirkausschuss für den Regierungsbezirk Danzig, Nr 1), zaś dla rejencji kwidzyńskiej zachowały się wyłącznie akta spraw wywłaszczeniowych, związanych z rozbudową sieci dróg, kolei i dla celów militarnych (XIV HA Rep 183 Bezirksrat / Bezirksauschuss fur den Regierungsbezirk Marienwerder). 
nictwo OVG w odniesieniu do praw podstawowych przez długi czas nie stało się przedmiotem rzetelnych opracowań, nad czym jeszcze w 1993 r. ubolewał Michael Kotulla ${ }^{40}$. Sytuacja poprawiła się dopiero w późnych latach dziewięćdziesiątych. Badacze niemieccy zdają się powszechnie przypisywać rolę gwaranta przynajmniej najwyższej instancji - OVG i często podkreśla się w literaturze obecność w orzecznictwie wątku polskiej mniejszości, jak uczynił to chociażby Hansgeorg Bräutigam w broszurze wydanej z okazji stulecia sądownictwa administracyjnego w Berlinie w 1975 r.: Kennzeichend für die Rechtsprechung des Oberverwaltunggerichts ist u.a. der in mehreren Urteilen zur Theater-Zensur, zum Vereins- und Versammlungsrecht den polnischen Minderheiten gewährte Schutz ${ }^{41}$.

W kontekście wolności obywatelskich przywołać należy kilka płaszczyzn orzecznictwa sądów administracyjnych. $Z$ pewnością znaczenie miała właściwość w zakresie ustroju władz terytorialnych. Jak wspomniano, OVG wypowiadał się m.in. szeroko na temat przebiegu wyborów do organów stanowiących, jak Kreistagi, oraz zakresu uprawnień poszczególnych organów. Ważne jest także orzecznictwo w zakresie kwestii proceduralnych związanych z wyborami powiatowymi.

Szerzej zbadana została kwestia orzecznictwa OVG w zakresie właściwości organów w zakresie prawa zgromadzeń i stowarzyszeń. Praca Wichard$\mathrm{ta}^{42}$ odnosi się $\mathrm{w}$ jednej z części wprost do orzecznictwa wobec ,polnische Vereine", jako że właśnie wiele spraw związanych z interpretacją prawa stowarzyszeniowego, jak stosowanie języka polskiego podczas zgromadzeń, charakter zgromadzeń publicznych itp. wywoływało emocje wśród polskiej mniejszości, prowadziło do sporów prawnych i wielu sądowych rozstrzygnięć nawet na szczeblu OVG. Orzeczenia te nazywa Kotulla „spektakularnymi”, zwłaszcza w kontekście praktyki wykorzystywania przez organy administracyjne każdej okoliczności przeciwko polskim zgromadzeniom, której istnieniu autor nie zaprzecza ${ }^{43}$.

Do ważniejszych orzeczeń w tym zakresie, jeszcze pod rządami pruskiej ustawy stowarzyszeniowej ${ }^{44}$, należą te związane $\mathrm{z}$ decyzjami władz admini-

${ }^{40}$ M. Kotulla, Die konstitutionellen Grundrechte..., s. 332-333.

41 „Cechą wyróżniającą orzecznictwo Najwyższego Sądu Administracyjnego jest ochrona udzielona polskiej mniejszości w wielu wyrokach dotyczących cenzury teatralnej, prawa do stowarzyszeń i zgromadzeń” (tłum. własne). Cyt. Za: H. Bräutigam, Ein Jahrhundert Verwaltungsgerichtsbarkeit in Berlin, Berlin 1975 (Berliner Forum 8/75), s. 22.

${ }^{42}$ H.-J. Wichardt, Die Rechtsprechung des Königlich Preußischen Oberverwaltungsgericht zur Vereins- und Versammlungsfreiheit in der Zeit von 1875 bis 1914. Ein Beitrag zur Entwicklung des materiellen Rechtsstaats in Deutschland, Jur. Diss., Kiel 1976, passim.

${ }_{43}$ M. Kotulla, Die konstitutionellen Grundrechte..., s. 345-346.

44 Verordnung über die Verhütung eines die gesetzliche Freiheit und Ordnung gefährdenden Mißbrauchs des Versammlungs- und Vereigungsrechtes z 11 maja 1850 (GS, s. 277). 
stracyjnych o uznawaniu stowarzyszeń za polityczne ${ }^{45}$. Uznanie za takowe stowarzyszenia „Sokół”"46 czy stowarzyszeń należących do Arbeiterturnerbund OVG w pełni zaakceptowa ${ }^{47}$. Wielokrotnie wypowiadał się OVG o języku zgromadzeńn ${ }^{48}$ i ich miejscu, precyzując pojęcia zgromadzeń zamkniętych i pod gołym niebem ${ }^{49}$. Upomniał także przed nadużywaniem wydawania zakazu odbywania zgromadzeń w lokalach, przywołując szerszą regulację art. 29 ust. 1 konstytucji, wobec której środki restrykcyjne winne być stosowane w węższym wymiarze, o ile jednocześnie nie naruszały przepisów ustawy o zgromadzeniach ${ }^{50}$. Notabene organy administracyjne wyrażały stanowisko, że przepis konstytucyjny odnosił się wyłącznie do zgromadzeń niemieckojęzycznych, czemu sąd wyraźnie sprzeciwił się w orzeczeniu z 26 września 1876 r. ${ }^{51}$ i kwestię precyzował w dalszych ${ }^{52}$.

Wyróżnia się jednak wśród wyroków orzeczenie z 6 stycznia 1903 r. $^{53}$, w którym OVG, odnosząc się do specyfiki stosunków narodowościowych w Poznańskiem, wprost przyznaje:

Es ist gerichtsbekannt, dass diese infolge der nationalpolitischen Bestrebungen seit Jahren bestehenden Gegensätze eine besondere Verschärfung erfahren haben, seitdem das von Königlichen Landgerichte zu Gnesen im November 1901 gegen die Teilnehmer an dem sogenannten Wreschner Schulkrawalle gefällte Urteil von der polnischen Presse zum Ausgangspunkt von Verunglimpfungen des Deutschtums gemacht wurde. Besondere gesetzliche Maßnahmen zum Schutze des bedrohten Deutschtums erwiesen sich als notwendig, und weite Kreise der polnischen Bevölkerung befanden sich in einer Erregung, die in Gegenden mit gemischter polnischer und deutscher Einwohnerschaft gewaltsame Zusammenstöße befürchten ließ. Daß die Polizeibehörden, denen die Aufrechterhaltung der

45 Przykładowo wyrok OVG z 6 marca 1903 r. (PrVB1., t. 25, s. 284).

46 Wyrok OVG z 3 maja 1907 r. (Entscheidungen des OVG, t. 51, s. 234). Por. też wyrok OVG z 7 marca 1911 (PrVB1, t. 33, s. 162; także Rechtsprechung des OVG, 5. Ergänzungsband 1912, s. 783).

${ }^{47}$ Wyroki OVG z 12 czerwca 1901 i 18 lutego 1908 (Rechtsprechung des OVG, 5. Ergänzungsband 1912, s. 784).

${ }^{48}$ Wyrok OVG z 5 października 1897 r. (Entscheidungen des OVG, t. 32, s. 395); wyrok OVG z 21 listopada 1899 (PrVBl. t. 21, s. 264); w szczególności wyrok OVG z 20 marca 1903 r. (Entscheidungen des OVG, t. 43, s. 432), w którym sąd przywołuje stenogramy posiedzeń Izby Posłów, zawierające wypowiedzi dotyczące pierwszeństwa i roli mowy niemieckiej, i ocenia je krytycznie.

49 Wyrok OVG z 24 stycznia 1905 r. (Entscheidungen des OVG, t. 46, s. 435); wyrok OVG z 9 października 1903 (PrVBl. t. 25, s. 694); wyrok z 3 czerwca 1904 (Entscheidungen des OVG, t. 45 , s. 449).

${ }^{50}$ Wyrok z 30 stycznia 1903 r. (Entscheidungen des OVG t. 42, s. 419). Por. też M. Kotulla, Die konstitutionellen Grundrechte..., s. 346.

${ }^{51}$ Entscheidungen des OVG, t. 1, s. 347.

52 Wspomniany wyżej wyrok z 20 marca $1903 \mathrm{r}$.

53 Wyrok OVG z 6 stycznia 1903 r. (PrVBl. t. 25, s. 45; Rechtsprechung des OVG, 3. Ergänzungsband, 1906, s. 543). 
öffentlichen Ordnung und Sicherheit obliegt, in solchen Landesteilen, wo infolge irgendwelcher Gegensätze in der Bevölkerung eine Spannung besteht, bei der Beurteilung der Gefährlichkeit öffentlicher Aufzüge auf diesen außergewöhnlichen Umstand Rücksicht zu nehmen haben, folgt aus dem Grundsatze, daß die jeweiligen örtlichen und zeitlichen Verhältnisse zu Prüfung, ob eine gesetzlich vorgeschriebene Genehmigung zu einer Veranstaltung zu erteilen oder zu versagen sie, zu Grunde gelegt werden müssen ${ }^{54}$.

Wzrost liczby spraw tej kategorii zauważalny jest zwłaszcza po uchwaleniu przez Reichstag 19 kwietnia 1908 r. ustawy o stowarzyszeniach i zgromadzeniach $^{55}$. Nowa ustawa unifikacyjna, uznawana w Rzeszy za postępową (zniosła chociażby zakaz udziału kobiet w stowarzyszeniach organizujących zgromadzenia polityczne) i przywitana w zasadzie z zadowoleniem, utrudniła sytuację stowarzyszeń działających w zaborze pruskim czy Alzacji-Lotaryngii. Organy administracyjne zaczęly bowiem notorycznie zaliczać do politycznych towarzystwa muzyczne, śpiewacze, robotnicze czy rolnicze. Wobec tej kategorii związków zaostrzyły się wymogi administracyjne, jak nakaz zgłoszenia listy członków zarządu do właściwych organów policyjnych. Za niedopełnienie tych obowiązków, a było to zjawisko niemal powszechne, władze stowarzyszeń ponosiły odpowiedzialność administracyjno-karną. Równolegle jednak, po wyczerpaniu drogi administracyjnej, składały skargi na administracyjne potraktowanie tych organizacji jako politycznych ${ }^{56}$, z różnym skutkiem zresztą. Odpis akt procesu przeciwko stowarzyszeniu „Koło śpiewackie” z Wągrowca, który odbył się w 1911 r., dowodzi, że organy administracyjne tendencyjnie podchodziły do kwestii ustalenia rzeczywistego charakteru stowarzyszenia, z góry przesądzając, że ma ono charakter polityczny, gdyż członkami są wyłącznie Polacy i służy ono poprzez śpiewanie polskich pieśni pielęgnowaniu polskiego ducha narodowego. Przywołane w tej wykładni dowody (dotyczące np. zupełnie innych stowarzyszeń) budziły zdumienie, któ-

54 „Jest sądowi wiadome, że istniejące od lat okoliczności uległy zaostrzeniu na skutek dążeń narodowościowych, od kiedy wyrok królewskiego sądu rejonowego w Gnieźnie z listopada 1901 przeciwko uczestnikom tzw. burdy wrześnieńskiej stał się dla polskiej prasy punktem wyjścia do zniesławiania niemieckości. Szczególne środki ustawowe do ochrony zagrożonej niemieckości wydają się konieczne, szerokie kręgi polskiego społeczeństwa znalazły się we wzburzeniu, które nakazuje obawiać się incydentów przemocy w okolicach zamieszkałych przez mieszaną ludność polską i niemiecką. W takich częściach kraju, w których wśród ludności na skutek jakichkolwiek sprzeczności panuje napięcie, władze policyjne, na których spoczywa obowiązek utrzymania ładu i bezpieczeństwa, muszą brać wzgląd na te faktyczne okoliczności przy ocenie zagrożenia związanego z publicznymi wystąpieniami. Wynika to z zasady, że każdorazowo stosunki miejscowe i czasowe muszą stanowić podstawę do oceny, czy udzielić lub odmówić przewidzianej ustawą zgody na organizację wydarzenia" (tłum. własne).

55 Vereinsgesetz vom 19. April 1908 (Reichs-Gesetzblatt; dalej: RGBL, s. 151).

${ }^{56}$ GStaPK, XVI HA (Provinz Posen), Rep. 30 (Regierungsbezirk Bromberg), Nr 838 (Rechtsprechung zum Reichsvereinsgesetz). 
re podzielili również sędziowie OVG, przesądzając ostatecznie o zasadności skargi na decyzję prezesa rejencji bydgoskiej ${ }^{57}$.

W zakresie prawa zgromadzeń OVG przypomniał zakres pojęć „zgromadzenie publiczne" 58 i ,zgromadzenie polityczne" ${ }^{59}$. Orzekał o prawie obcokrajowców do udziału w stowarzyszeniach i zgromadzeniach ${ }^{60}$ oraz o czasie zgromadzenia $^{61}$. Wielokrotnie odnosił się do problemu zezwolenia na zgromadzenie pod otwartym niebem i jego cofnięcia ${ }^{62}$. Dla praw językowych polskiej mniejszości narodowej decydujące było uznanie zgromadzenia za publiczne - wówczas rozmowy (die Verhandlungen) musiały się odbywać w języku niemieckim ${ }^{63}$. Nakaz nie dotyczył kongresów międzynarodowych i zebrań wyborczych. Dopuszczalność używania innego języka określać miało ustawodawstwo krajów związkowych. Wyjątkiem w ciągu pierwszych dwudziestu lat obowiązywania ustawy miało być prawo używania podczas zgromadzenia języka innego niż niemiecki na obszarach zamieszkałych przez ponad $60 \%$ populacji mówiącej innym językiem, pod warunkiem trzykrotnego zgłoszenia tego faktu na 24 godziny przed rozpoczęciem spotkania. Powiatów, w których wedle ostatniego spisu zamieszkiwało ponad $60 \%$ ludności polskiej, było stosunkowo niewiele. Absurdalny, a wcale nie jednostkowy charakter miała w tym zakresie sprawa Ludwika Makowskiego, organizatora spotkania w 100. rocznicę urodzin Chopina. Ponieważ organy administracji odmówiły zgody na mówienie po polsku, Makowski powiedział tylko na początku spotkania, że „wstęp i wykład zostały zakazane przez ministerstwo” i po części muzycznej zakończył spotkanie słowami: „Chwała Chopinowi”. Jego sprawa karna ciągnęła się przez trzy instancje i dopiero sąd okręgo-

57 Ibidem, k. 531 -536; sygn. akt sprawy przed OVG z 12 czerwca 1911 r. I A 12.10.

58 Wyrok OVG z 4 czerwca 1909 r. (Entscheidungen des Pr. OVG, t. 54, s. 281; Rechtsprechung des OVG, 5. Ergänzungsband 1912, s. 787). Wykaz orzeczeń w tej kwestii zob. Rechtsprechung des OVG, 5. Ergänzungsband 1912, s. 788-789.

59 Wyrok OVG z 18 lutego 1910 r. (Entscheidungen des Pr. OVG, t. 56, s. 299 ; PrVB1. t. 32, s. 596; Rechtsprechung des OVG, 5. Ergänzungsband 1912, s. 789)

${ }^{60}$ Wyrok OVG z 20 listopada 1908 r. (Entscheidungen des Pr. OVG, t. 53, s. 265; PrVB1. t. 30, s. 321; Rechtsprechung des OVG, 5. Ergänzungsband 1912, s. 789).

${ }^{61}$ Wyrok OVG z 20 września 1910 r. (PrVB1. t. 32, s. 414; Rechtsprechung des OVG, 5. Ergänzungsband 1912, s. 790).

62 Wyrok OVG z 12 lutego 1909 r. (Entscheidungen des Pr. OVG, t. 53, s. 262; Rechtsprechung des OVG, 5. Ergänzungsband 1912, s. 793); wyrok OVG z 9 listopada 1909 r. (Entscheidungen des Pr. OVG, t. 55, s. 277; Rechtsprechung des OVG, 5. Ergänzungsband 1912, s. 791); wyrok z 12 kwietnia 1910 (Entscheidungen des Pr. OVG, t. 56, s. 308); wyrok OVG z 7 czerwca 1910 r. (Entscheidungen des Pr. OVG, t. 57, s. 65); wyrok OVG z 15 listopada 1910 r. (Entscheidungen des Pr. OVG, t. 57, s. 315); wyrok OVG z 6 grudnia 1910 r. (PrVBl. t. 33, s. 6); wyrok z 6 stycznia 1911 (PrVB1. t. 32, s. 809); wyrok OVG z 24 stycznia 1911 r. (PrVB1. t. 32, s. 747); wyroki z 22 marca 1911 r. (Entscheidungen des Pr. OVG, t. 59, s. 294 i 296); wyrok OVG z 2 maja 1911 r. (Entscheidungen der Pr. OVG, t. 59, s. 299).

${ }^{63} \S 12$ zd. 1 ustawy Rzeszy o zgromadzeniach, tzw. Sprachenparagraph. Zob. też wyrok OVG z 24 maja 1910 r. (Entscheidungen des Pr. OVG, t. 56, s. 330); wyrok z 15 listopada 1910 r. (Entscheidungen des Pr. OVG, t. 57, s. 315). 
wy w Kwidzynie, rozwodząc się szeroko nad pojęciem „rozmowy”, uznał go winnego zarzutu ,rozmów po polsku” i skazał na grzywnę w wysokości 3 marek $^{64}$. Organy administracyjne i wtórnie sądy powszechne bardzo często zresztą uznawały zgromadzenia organizowane przez polskie stowarzyszenia za publiczne. Z kolei w orzeczeniu z 20 września 1910 r. OVG stwierdził niemożność zaskarżenia w postępowaniu sporno-administracyjnym ,wzbraniania się władz krajowych od dopuszczania wyjątków od reguły, że rozmowy podczas zgromadzeń publicznych muszą być prowadzone po niemiecku", gdyż nie jest to rozporządzenie policyjne ${ }^{65}$. Ostatecznie paragraf językowy zniesiono w 1917 r. ${ }^{66}$ Spraw dotyczących ustawy stowarzyszeniowej znalazło się przed OVG wiele i w dużej części miały one pośrednio lub bezpośrednio znaczenie dla mniejszości polskiej. Z kolei orzecznictwo Senatu Karnego Sądu Kameralnego w tym zakresie można, poza wydawnictwem oficjalnym Senatu, prześledzić na łamach „Deutsche Juristen-Zeitung”.

Podstawę prawną w zakresie prawa prasowego stanowiła ustawa prasowa z 12 maja 1851 r. $^{67}$ Ustawa ta praktycznie wyhamowała działalność niezależnej prasy w Poznańskiem. Poddała ona drukarnie, wydawnictwa i handel książkami wymogowi uzyskania koncesji; wydawcy wpłacali wysoką kaucję na poczet ewentualnych przyszłych naruszeń prawa prasowego. Ustawa wprowadzała cenzurę następczą. Formalnie administracja mogła zarządzać samodzielnie konfiskatę druku tylko w szczególnych przypadkach, wymienionych w $\S 75$ (obraza majestatu), 100 (zagrożenie spokoju publicznego) i 101 (zniesławienie instytucji publicznych, ,Schmähung staatlicher Einrichtungen") ustawy oraz w razie zagrożenia wykonalności, w innych przypadkach wymagana była zgoda sądu. Jednak Albrecht Funk w swojej wartościowej publikacji celnie zauważa: „Doch die Wirklichkeit sah anders aus. Es war die Polizeibehörde, die Zeitungen schon in der Nacht durch mehrere Lektoren durchsehen ließ und sofort am Morgen zur Tat schritt, zu einem Zeitpunkt, als die Justiz noch im Bette lag" ${ }^{\prime 6}$.

${ }^{64}$ Opis akt sprawy w niższych instancjach: GStaPK, XVI HA (Provinz Posen), Rep. 30 (Regierungsbezirk Bromberg), Nr 838 (Rechtsprechung zum Reichsvereinsgesetz), k. 446 i n., posiedzenie sądu w Kwidzynie (sygn. akt 3. S.176/10) k. 448-449.

${ }^{65}$ „Die Weigerung der landeszentralbehörde, Ausnahmen von der Regel zuzulassen, daß die Verhändlungen in öffentlichen Versammlungen in deutscher Sprache zu führen sind (...), stellt keine polizeiliche Verfügung [...]”. Wyrok OVG z 20 września 1910 r. (Entscheidungen des Pr. OVG, t. 57 , s. 333).

${ }^{66}$ Gesetz betreffend die Abänderung des Vereinsgesetzes vom 19. April 1908 (RGB1. 1917, S. 361).

${ }^{67}$ Gesetz über die Presse vom 12 Mai 1851 (GS, s. 273).

68 „Rzeczywistość wyglądała zgoła inaczej. Zdarzały się władze policyjne, które nakazywały rozlicznym lektorom przegląd czasopism już w nocy i przystępowały do działania rano, w momencie, gdy władza sądowa leżała jeszcze w łóżku" (tłum. własne). A. Funk, Polizei und Rechtsstaat. Die Entwicklung des staatlichen Gewaltmonopols in Preußen 1848-1918, Frankfurt am Main 1986, s. 78. 
Od 1874 r. prawo prasowe regulowała ustawa Rzeszy ${ }^{69}$. Stosunkowo rzadkie były orzeczenia OVG w zakresie prawa prasowego ${ }^{70}$. Choć generalnie cenzura została zniesiona, nadal utrzymano ją dla przedstawień teatralnych. $\mathrm{Z}$ tą kwestią wiąże się jedna $\mathrm{z}$ najsłynniejszych spraw OVG, w której zapadły tzw. Weber-Urteile (z 2 października 1893 r., 2 czerwca 1894 r. i 15 października 1896 r.). Przedmiotem sporu stał się policyjny zakaz wystawienia dramatu Gerharta Hauptmanna „Tkacze” (,Die Weber”), rzekomo z obawy przed rozruchami, do których mogło dojść pod wpływem propagandy socjalistycznej obecnej w sztuce. OVG uchylił przepisy policyjne, a prapremiera 25 września 1894 r. w Teatrze Niemieckim w Berlinie zakończyła się wielkim wybuchem entuzjazmu. Wyrok wywołał „wojnę prasową” i gorąca debatę w Landtagu z problemem cenzury językowej w tle. Poseł Motty, reprezentujący polską mniejszość, kwestionował rozporządzenie z 1894 r., w którym nakazywano przedłożenie władzom uwierzytelnionego tłumaczenia sztuk w języku polskim na niemiecki ${ }^{71}$. Cesarz demonstracyjnie zrezygnował z loży w tamtejszym teatrze i wysłał do prezesa OVG telegram, w którym stwierdził, że demoralizująca sztuka nie powinna być wystawiona. Sędziowie nie ugięli się pod presją, podtrzymując swe stanowisko w kolejnych wyrokach, dotyczących wystawień sztuki w innych miastach ${ }^{72}$. Spór nie zaszkodził prezesowi Persiusowi, który w 1896 r. został odznaczony przez cesarza najpierw orderem czerwonego orła I klasy z liśćmi dębowymi, a odchodząc ze służby w 1902 - wyjątkowym, nie przewidzianym przez statut kapituły orderu dodatkiem - brylantami ${ }^{73}$.

W zakresie spraw szkolnych znaczenie mogą mieć sprawy klasyfikowane jako sprawy szkół wyznaniowych ${ }^{74}$, dominują, jak wspomniano, spory związane z utrzymaniem finansowym szkół i nauczycieli. Sprawy wynikłe na tle ustawy z 1906 r. ${ }^{75}$, wchodzącej w życie 1 kwietnia 1908 r., nie były traktowane odrębnie.

${ }^{69}$ Gesetz über die Presse vom 7. Mai 1874 (RGB1, s. 65).

70 Wyrok OVG z 16 lutego 1909 r. (Entscheidungen des Pr. OVG, t. 54, s. 241; Rechtsprechung des OVG, 5. Ergänzungsband 1912, s. 799), dotyczący pojęcia ,informacji dla celów reklamowych"; wyrok z 24 czerwca 1910 r. (Entscheidungen des Pr. OVG, t. 57, s. 305; Rechtsprechung des OVG, 5. Ergänzungsband 1912, s. 799), dotyczący zezwolenia na rozdawnictwo ulotek.

71 Zob. Stenographische Berichte über die Verhandlungen der durch die Allerhöchste Verordnung vom 30. Dezember 1894 einberufenen beiden Häuser des Landtages, Haus Der Abgeordneten, Erster Band, Von den Eröffnungssitzung der vereinigten beiden Häuser des Landtages am 15. Januar 1895 bis zur Sitzung am 21. Februar 1895, Berlin 1895, s. 789-796.

72 Wydarzeniom tym jest poświęcona praca M. Pagenkopfa, Das Preußische OVG und Hauptmanns ,, Weber”. Ein Nachtrag zum 125. Geburtstag von Gerhart Hauptmann, Bonn 1988, passim.

${ }^{73}$ H. Bräutigam, op. cit., s. 29.

74 Wyrok OVG z 8 lutego 1907 r.

75 Gesetz betreffend die Unterhaltung der öffentlichen Volkschulen z 28 czerwca $1906 r$. (GS. S. 335). 
Władze „polskich” prowincji śledziły bacznie orzecznictwo sądów również innych prowincji pruskich, czego dowodzą odpisy zachowane w ak$\operatorname{tach}^{76}$. Dla rejencji przygotowywano też wyciągi ze wspomnianej „Deutsche Juristen-Zeitung" ${ }^{\prime 77}$.

W grę wchodzi wreszcie problem świadomości prawnej zainteresowanych. Wyraźnie wskazywał na to ton notki prasowej ${ }^{78}$, w której redaktor podkreślał, że dopiero po znalezieniu obrotnego adwokata, który odważył się na zaskarżenie do OVG kary policyjnej za śpiewanie polskich pieśni przez wędrujących muzyków (kary te podtrzymał sąd administracyjny rejencji poznańskiej), sąd berliński podważył przepisy wydane przez rejencję i uwolnił grajka od kary. Stosunkowo rzadko sięgano jednak po adwokata, i to na tyle doświadczonego, by reprezentować stronę w procesie przed OVG; decydowała o tym i świadomość prawna, i koszty. Natomiast zachowane akta dowodzą, że w sprawach karnych decydowano się na apelację i rewizję, z reguły jednak sądy wyższych instancji podtrzymywały wyroki skazujące lub też skazywały, gdy apelację wnosił prokurator. Rola uświadamiająca polskiej prasy jest w tym aspekcie nie do przecenienia.

VI. Rola sądów administracyjnych jako gwarantów podmiotowych praw publicznych, a więc polityczno-wolnościowy wymiar działalności sądów pozostaje nieco na uboczu we wcześniejszym okresie ich działalności. Aktywność sądów można uznać za przeciwdziałanie „die Willkür der Verwaltung, nicht gegen eine Verfügung des Gesetzgebers"79. Poważniejszego znaczenia w kontekście badanego problemu mogą nabrać orzeczenia OVG piętnujące błędy formalne, popełnione $\mathrm{w}$ toku postępowań administracyjnych i rozwiązujące konflikty kompetencyjne.

Wraz z uchwalaniem ustaw Rzeszy rola OVG jako gwaranta praw podmiotowych rosła, gdyż wzrastała liczba orzeczeń, w których OVG odnosił się do treści i znaczenia praw podstawowych. Nieraz narażał się przez to na ataki polityczne, zarówno ze strony lewicy, jak i konserwatystów. Rozstrzygał kontrowersyjne sprawy cenzury, zgromadzeń, stowarzyszeń, wydając słynne wyroki, jak np. w sprawie pomnika ku czci poległych (Kriegerdenkmal) na Kreuzburgu (z 14 czerwca 1882 r. $)^{80}$ czy wspomniane orzeczenia w sprawie „Tkaczy”. W oczach późniejszego prezesa Związkowego Sądu Administracyjnego (Bundesverwaltungsgericht) Ludwiga Fregego OVG postrzegany był

76 Por. przykładowo GStaPK, XVI HA (Provinz Posen), Rep. 30 (Regierungsbezirk Bromberg), Nr 838 (Rechtsprechung zum Reichsvereinsgesetz), k. 50-52.

77 Ibidem, k. 80-92, 95, kolejne.

78 Polak, Nr 8 z sierpnia 1900, s. 126.

79 „[...] samowoli administracji, nie rozporządzeniu prawodawcy” (tłum. własne). Za: U. Scheuner, Die rechtliche Tragweite..., s. 159.

${ }^{80}$ Entscheidungen des OVG, t. 9, s. 535. 
idealistycznie jako: „Hüterin der Rechtsstaatlichkeit [...]. Aus seinen Urteilen ist deutlich ersichtlich, daß seine durchaus nicht formalistische, von einem starken Gerechtigkeitswillen getragene Rechtsprechung geleitet war von dem Bestreben, dem Schwachen gegenüber dem Mächtigen zu seinem Recht zu verhelfen" $"$.

$\mathrm{Na}$ ile pruskie sądownictwo administracyjne służyło mniejszości polskiej? Wstępne ustalenia prowadzą do stwierdzenia, że OVG niejednokrotnie pozostawał deską ratunku w tych przypadkach, gdy upolitycznione sądy w rejencjach (przykładem poznańska czy kwidzyńska) podtrzymywały zaskarżane przepisy policyjne w mocy. Procesy toczyły się ze zmiennym szczęściem dla narodowych interesów polskich, jednak trudno dostrzec, by orzeczenia OVG w bardziej zauważalnym stopniu miały być podyktowane polityką państwową. Jak się zdaje, powyżej cytowane orzeczenie ze stycznia 1903 r. ma jednostkowy charakter, kwestia wymaga pogłębionej kwerendy. Akta dowodzą jednak, że OVG wielokrotnie zwracał uwagę na niedostatki dowodowe ze strony skarżonych władz administracyjnych i wyłapywał absurdy w logice ich wywodów.

Pruskie Rechtsstaat to państwo prawa proceduralnego. Czy jednak pozytywistyczna miłość do ścisłych i klarownych reguł postępowania oraz ich nienaruszalności zastąpić może materialne wartości państwa prawa? Czy specyficzne przewartościowanie państwa prawa w kierunku ,związania aparatu państwa nie tyle podmiotowymi prawa obywateli, co prawem przedmiotowym, wyznaczającym granice jego działalności" ${ }^{2}$ stanowić może pełny ekwiwalent klasycznie pojmowanego kanonu państwa prawa? Na to pytanie brak jeszcze pełnej odpowiedzi i taki projekt badawczy wart jest pogłębionych ustaleń.

\section{Bibliografia}

1. Bar L., Sadowa kontrola administracji w Anglii, Warszawa 1962

2. Bähr O., Der Rechtsstat. Eine publizistische Skizze, 2. unveränd. Aufl., KasselGöttingen 1864

3. Bräutigam H., Ein Jahrhundert Verwaltungsgerichtsbarkeit in Berlin, Berlin 1975 (Berliner Forum 8/75)

4. Dziadzio A., Monarchia konstytucyjna w Austrii 1867-1914 (Wtadza, obywatel, prawo), Kraków 2001

81 „Strażnik praworządności [...]. Z wyroków wyraźnie wynika, że jego całkowicie nieformalistyczne, nacechowane silną wolą czynienia sprawiedliwości orzecznictwo kierowało się dążeniem, by wspomóc słabego w jego prawie wobec potężnego" (tłum. własne). Cyt. za: H. Bräutigam, op. cit., s. 22.

${ }^{82}$ Cyt. za: A. Dziadzio, Ochrona konstytucyjności prawa..., s. 175. 
5. Dziadzio A., Koncepcja państwa prawa w XIX w. - idea i rzeczywistość, „Czasopismo Prawno-Historyczne" 57 (2005), z. 1

6. Dziadzio A., Ochrona konstytucyjności prawa w Europie XIX wieku, „Studia z Dziejów Państwa i Prawa Polskiego" 11 (2008)

7. Dziadzio A., Znaczenie najwyższych trybunatów sadowych w tworzeniu podstaw państwa prawa w austriackiej monarchii konstytucyjnej po 1867 roku, [w:] Świat, Europa, Mała Ojczyzna. Studia ofiarowane Profesorowi Stanisławowi Grodziskiemu w 80-lecie urodzin, red. M. Małecki, Bielsko-Biała 2009, s. 419-425

8. Eimer A.J., Proces wrzesiński w świetle dokumentów sadowych, Poznań 1927

9. Esser D., Gneist, Rudolf [w:] Juristen. Ein biographisches Lexikon, hrsg. von M. Stolleis, München 1995, s. 238-239

10. Funk A., Polizei und Rechtsstaat. Die Entwicklung des staatlichen Gewaltmonopols in Preußen 1848-1918, Frankfurt am Main 1986

11. Giese F., Die Grundrechte, Tübingen 1905

12. Gneist R. v., Der Rechtsstaat und die Verwaltungsgeschichte, 1879

13. Grimm D., Die Entwicklung der Grundrechtstheorie in der deutschen Staatsrechtslehre des 19. Jahrhunderts, [w:] Grund- und Freiheitsrechte von der ständischen zur spätbürgerlichen Gesellschaft, hrsg. von G. Birtsch, Göttingen 1987, s. $234-266$

14. Grot Z., Sprawa wrzesińska, „Przegląd Zachodni”, R. 7 (1951), nr 9/10, s. $72-131$

15. Henne T., Verwaltungsrechtsschutz im Justizstaat. Das Beispiel des Herzogtums Braunschweig 1832-1896, Frankfurt am Main 1995

16. Huber E.R., Deutsche Verfassungsgeschichte seit 1789, Bd. III: Bismarck und das Reich, 3. überarb. Aufl., Stuttgart 1988

17. Huber E.R., Deutsche Verfassungsgeschichte seit 1789, Bd. IV: Struktur und Krisen des Kaiserreiches, Stuttgart 1969

18. Huber E. R., Grundrechte im Bismarkschen Reichsystem, [w:] H. Ehmke, J.H. Kaiser, W.A. Kewenig, K.M. Meessen, W. Rüfner, Festschrift für Ulrich Scheuer zum 70. Geburtstag, Berlin 1973, s. 163-181

19. Ibler M., Rechtspflegender Rechtsschutz im Verwaltungsrecht. Zur Kontrolldichte bei wertenden Behördenentscheidungen - vom Preußischen Oberverwaltungsgericht bis zum modernen Gerichtsschutz im Prüfungsrecht, Tübingen 1999

22. Jellinek G., Die Erklärung der Menchen- und Bürgerrechte. Ein Beitrag zur modernen Verfassungsgeschichte, 3 Aufl., München-Leipzig 1919

21. Korth R., Die preussische Schulpolitik und die polnischen Schulstreiks. Ein Beitrag zur polnischen Polenpolitik der Ära Bülow, Würzburg 1963

22. Kotulla M., Die konstitutionellen Grundrechte in der Rechtsprechung des Preußischen Oberverwaltungsgerichts bis 1918, [w:] Vorträge zur Justizforschung. Geschichte und Theorie, hrsg. von H. Mohhaupt, D. Simon Bd. 2.; Rechtsprechung. Materialien und Studien, Veröffentlichungen des Max-Planck-Instituts für Europäische Rechtsgeschichte, Frankfurt am Main, Bd. 7, 1993, s. $331-368$

23. Kozłowski J., Wielkopolska pod zaborem pruskim w latach 1815-1918, Poznań 2006

24. Langrod J., Zarys sądownictwa administracyjnego, Warszawa 1925 
25. Müller O., Die Verfassungsbeschwerde nach Bayerischen Verfassung von 1818 (1818-1848). Ein Beitrag zur Geschichte der Verfassungs- und Verfassungsgerichtsbarkeit in Deutschland, Frankfurt am Main 2000

26. Nowatius N., Die Einführung der Verwaltungsgerichtsbarkeit in Preußen durch die Kreisordnung von 1872 unter besonderer Berücksichtigung der Verdienste von Eduard Lasker (Jur. Diss.), [b.m.w.] 2000

27. Obracht-Prondzyński C., Ku samorządnemu Pomorzu. Szkice o kształtowaniu się ładu demokratycznego, Gdańsk 2002

28. Pagenkopf M., Das Preußische OVG und Hauptmanns „,Weber”. Ein Nachtrag zum 125. Geburtstag von Gerhart Hauptmann, Bonn 1988

29. Pahlow L., Administrativjustiz versus Justizstaat. Justiz und Verwaltung im Allgemeinen Staatsrecht des 18. und 19. Jahrhunderts, „Zeitschrift für neuere Rechtsgeschichte", 22. Jg, 2000, Nr 1

30. Scheuner U., Die rechtliche Tragweite der Grundrechte in der deutschen Verfassungsentwicklung des 19. Jahrhunderts, [w:] Festschrift für Ernst Rudolf Huber. Zum 70. Geburtstag am 8. Juni 1973, hrsg. von E. Forsthoff, W. Weber, F. Wieakker, Göttingen 1973, s. 139-165

31. Schieder T., Das Deutsche Kaiserreich von 1871 als Nationalstaat, KölnOpladen 1961

32. Sydow G., Die Verwaltungsgerichtsbarkeit des ausgehenden 19. Jahrhunderts. Eine Quellenstudie zu Baden, Württemberg und Bayern mit einem Anhang archivalischer und parlamentarischen Quellen, Heidelberg 2000

33. Unruh G.-Ch. v., Verwaltungsgerichtsbarkeit im Verfassungsstaat, Herford 1984

34. Unruh G.-Ch. v., Die Verwaltungsrechtsschutz in Preussen und seine Bedeutung für die rechtsstaatliche Entwicklung in Deutschland, [w:] Forschungen zur brandenburgischen und preussischen Geschichte, Neue Folge, Bd. 4 (1994)

35. Wichardt H.-J., Die Rechtsprechung des Königlich Preußischen Oberverwaltungsgericht zur Vereins- und Versammlungsfreiheit in der Zeit von 1875 bis 1914. Ein Beitrag zur Entwicklung des materiellen Rechtsstaats in Deutschland, Jur. Diss., Kiel 1976

36. Die Zuständigkeit der Preußischen Verwaltungsgerichts und Beschlußbehörden. Nach den Gesetzen und den dazu ergangenen Ausführungsbestimmungen, Berlin 1911 


\author{
PRUSSIAN ADMINISTRATIVE COURTS AS GUARANTORS \\ OF SUBJECTIVE RIGHTS? THE ORGANIZATION OF COURTS \\ AND JUDICIAL PRACTICE OF THE SUPREME ADMINISTRATIVE COURT \\ (SAC) AND THE RIGHTS OF THE POLISH MINORITY \\ BETWEEN 1875 AND 1914
}

Summary

The organization and selected aspects of the judicial decisions delivered by the administrative courts in the State of Prussia have been analyzed, with a particular focus put on the Supreme Administrative Court (SAC) in Berlin as the only court exclusively composed of professional judges and at the same time a court of the highest instance, considered in the literature a guarantor of civil rights, including the rights of the Polish minority inhabiting the eastern provinces of the Prussian State. The author attempts to verify the latter thesis by analyzing the system of civil rights in the Prussian state and examining the scope of the matters adjudicated by the SAC, pointing to the most important ones that concerned the freedom of association, assemblies and the press.

\title{
LES TRIBUNAUX ADMINISTRATIFS DE PRUSSE COMME LE GARANT DES DROITS SUBJECTIFS ? L'ORGANISATION DES TRIBUNAUX ET LA PRATIQUE JURISPRUDENTIELLE OVG FACE AUX DROITS DE LA MINORITÉ NATIONALE POLONAISE (1875-1914)
}

\section{Résumé}

La présente élaboration analyse l'organisation et certains aspects de la jurisprudence des tribunaux administratifs au sein de l'État de Prusse et notamment la question relative à la Haute Cour Administrative (OVG) en tant que tribunal unique, dont la composition est exclusivement professionnelle et de la plus haute instance, considérée par la littérature spécialisée en tant que garant particulier des droits de citoyen, également par rapport à la minorité polonaise résidant aux provinces de l'est. Grâce aux tentatives de vérification de cette dernière thèse dans le contexte du système de droits civils dans l'État de Prusse, le champ d'application des décisions de justice OVG a été analysé en relevant les plus pertinentes d'entre elles concernant la liberté d'association, de réunion et de la presse. 
